\title{
Planning for the Subernarekha river system in Eastern India
}

\author{
BASAWAN SINHA*, RAMESH BHATIA** and SUPRIYA LAHIRI $\dagger$ \\ *Central Flood Forecasting, Central Water Commission, "Kamata Sadan", 427/C, East \\ Borning, Canal Road, Patna 800001, India \\ **Institute of Economic Growth, University of Delhi, Delhi 110007, India \\ † MIT Energy Laboratory, MIT, Cambridge, MA 02138, USA
}

\begin{abstract}
The study describes the systems studies carried out to plan a river basin in order to determine the nature and size of water storage facilities and releases for irrigation and industrial uses, and the associated cropping pattern. The model has been formulated in the framework of a linear programming model for a specific target year. This model is developed in the context of planning the Subernarekha river basin. The results are discussed and these provide information and insight suggesting the need for more disaggregated analysis of interaction between irrigation and related agroeconomic parameters.
\end{abstract}

Keywords. River basin planning; LP model; storages; Subernarekha river system; agroeconomic parameters.

\section{Introduction}

The Subernarekha is an inter-state river flowing through Bihar, West Bengal and Orissa. It rises in the Chhotanagpur plateau of Bihar and flows into the Bay of Bengal. The upper part of the Subernarekha and its tributaries run through the fertile land of Bihar, but the farming in this region is mainly dependent on the inadequate and untimely rains, and the water resources of the Subernarekha river system remain largely untapped. The upper basin, besides containing fertile land, also contains large reserves of minerals. A number of important industries have therefore grown along the banks of the river.

For integrated development of this basin the construction of dams, one on the Subernarekha at Chandil and the other on its tributary Karkai and two barrages, one on the Karkai at Bhua and the other on the Subernarekha at Galudih, is proposed. The gross irrigated area envisaged under this programme is about $2,30,000$ ha in Bihar.

This study aims at an economic appraisal of the scheme in a coordinated manner to determine the nature and size of the water storage facilities and the releases for irrigation and industrial uses as well as the associated cropping patterns such that the water potential in this region is exploited optimally.

Detailed systems analysis studies are required for this purpose which incorporate the interactions of hydrological, agronomic and economic considerations in an integrated manner. Initially the model was formulated in the framework of a linear programming (LP) model for a specific target year which would take into account some of the chief interrelated factors affecting the optimum utilization of the water potential in this area. Since the projects mainly benefit the agricultural sector, both the cropping pattern and

A list of symbols $\&$ indices is given at the end of the paper. 
the capacities of the dams and barrages with their associated canals were considered as choice variables in the model. The idea was to provide a logical framework so that the initial results could provide some useful information and insights for subsequent systems studies with detailed (multiperiod) programming models or simulation models which may be useful for obtaining the capacities and operational schedule of the system.

\section{An overview of the model}

The target year LP model for 1980 as outlined above is disaggregated over space and considers temporal differentiation (in terms of the 12 months) over a year. A schematic diagram of the Subernarekha river system is presented in figure 1. The objective of our model is to maximise the annual additional benefits considering returns from the crop, the supply of industrial water, net project costs, farm costs and benefits foregone. All such benefits and costs have been computed from society's point of view.

\subsection{Decision variables}

The LP problem determines the following investment decision variables:

(i) Capacities of the reservoirs to be built at each of the two sites,

(ii) Delivery capacity of the associated canal system.

The associated operating decision variables evaluated by the model are the following:

(i) For each crop, the area sown, where production activities are differentiated by site,

(ii) The amount of industrial water to be supplied from each site during each month.

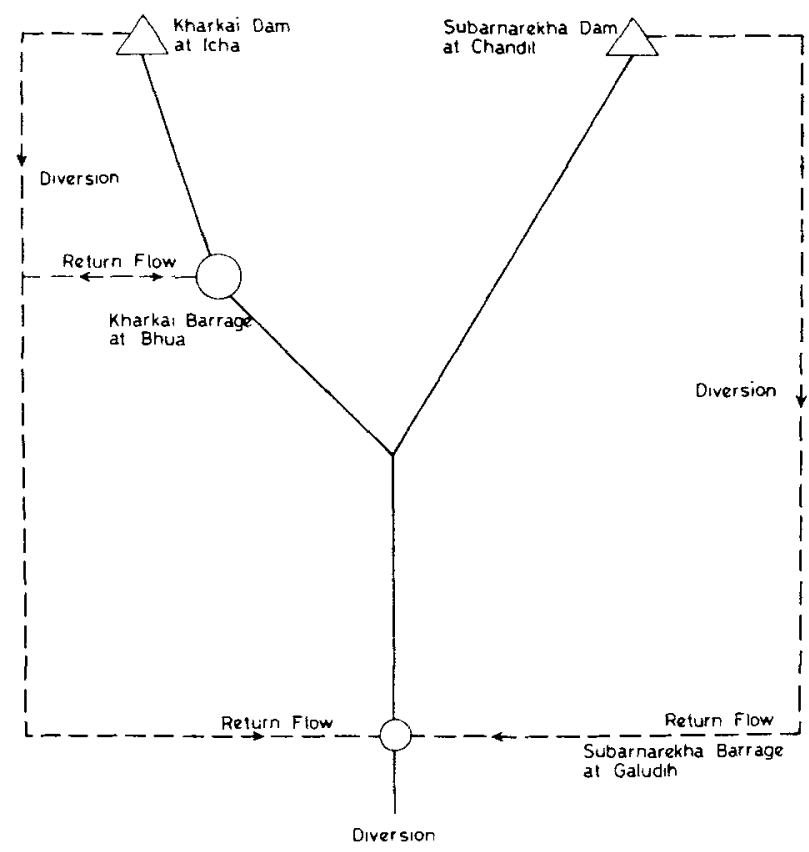

Figure 1. Schematic outline of the Subernarekha river basin 
(iii) The downstream flows from each of the dams and barrages during each month.

(iv) The diversion for irrigation purposes from each site in each month.

(v) Volume of water to be stored by the end of each month for the subsequent periods.

\subsection{Constraints}

The levels of both the investment decision variables and operating decision variables are simultaneously determined in the model such that the total additional benefit to society, less the project costs, is maximized subject to the following constraints of continuity, capacity, agronomy and land area.

(i) The flow continuity constraint for the dams for each period states that the inflows should equal the outflows plus the water that is stored for the next period. The water that is stored for the next period should not go below a minimum level (i.e. the dead storage level). Since there are no storage facilities in barrages, the flow continuity constraints simply require that the inflows should equal the outflows from such modes.

(ii) The capacity constraints for dams require that the volume of water to be stored in each decision period should not exceed the capacity of the dam to be built at that site. Similarly, the amount of water for irrigation purposes in each period should not exceed the delivery capacity of the canal.

(iii) The irrigation flow constraints state that the amount of water diverted for irrigation purposes each month should be at least as large as the water requirements of perennial and non-perennial crops.

(iv) The land area constraint requires that the total planting in each season should be restricted to the culturable command area less the acreage required for fodder crops and the area left fallow in a particular season.

(v) Certain limits have also been imposed on the production of certain crops (for example, vegetables) as commodity demand functions have not been included in our model. Certain constraints have also been introduced on the acreage under paddy to reflect consumer preference for rice.

Detailed sensitivity analyses have also been carried out on different assumptions with respect to the river flow data and detailed parametric programming has also been performed on the coefficients of the objective functions (especially with respect to changes in the relative price of wheat to that of other crops) for mapping out the different patterns of irrigation development with respect to changes in the above parameters.

\section{The algebraic formulation of the model}

The mathematical model is described by (A1)-(A14) (appendix A). There are four sites considered in the model which are differentiated by the subscript $i$ (see list of symbols $\&$ indices).

Fourteen crops have been considered indexed by $t$. Irrigated crops with different levels of irrigation have been designated as different crops. The figures in brackets denote water supplied corresponding to which appropriate yields are adopted.

The activities or choice variables, of which the two land use activities are measured in thousand hectares and all the remaining which are hydrologic activities, are measured in million cubic metres. 


\section{Data base}

The main data inputs for the model are: benefit and cost coefficients in the objective function, water requirements of various crops for each month, hydrological inputs for different months at various sites, downstream flow requirements at the Subernarekha barrage for downstream use, coefficients of return flows from irrigation and industrial water supplies and coefficients of reservoir losses in each month.

In the objective function, the coefficients required are: value of each crop net of variable farm costs, fixed farm costs, unit revenue from the sale of industrial water, the annualized investment costs of reservoirs and canals and annual maintenance costs of reservoirs and canals. Gross value of each crop has been estimated as the sum of the value of grain output and the value of fodder. The assumptions regarding yield rates, prices and value of output have been given in table 1 . The yield rates are based on the data obtained from the Agriculture Department (Ministry of Agriculture 1971) and from the Project Report (Ministry of Irrigation and Power 1972). The yield of paddy is assumed to decline by $10 \%$ when the total water requirements (at canal head) are reduced from 75 to $67.5 \mathrm{~cm}$. Similarly, the yield of wheat is assumed to be $10 \%$ lower when the tc al water input is reduced from 70 to $57.5 \mathrm{~cm}$. The accounting (or shadow) prices used to estimate benefits from major crops are expected to reflect the social value of these agricultural commodities since these prices take into account (i) economic cost of production of additional foodgrains in a surplus region of the country plus (ii) the economic cost of transportation (including cost of distribution and storage) of these commodities to the project region. We have used prices of foodgrains fixed by the Agricultural Prices Commission in the nearest surplus region plus the average cost of transporting these commodities to the project region (Sinha $\&$ Bhatia 1976). Valuation of agricultural output on this basis is expected to reflect the need for increasing agricultural output in regions away from the granaries of the country. The net value of each crop has been estimated by deducting the cost of seeds, fertilizers and manures, pesticides and human labour. To reflect the relatively higher levels of unemployment of unskilled agricultural labour in the region, we have used shadiow wage rates which are lower than the market wages. We have assumed the ratio of shadow wages to market wages to be $0 \cdot 25$. The estimated values for various elements of variable costs and net benefit for each crop are given in tables 2 and 3 . The fixed farm costs are assumed to include the following elements: (i) annualized costs of additional bullocks and implements required in irrigated agriculture, (ii) annual costs of maintenance of bullocks, command area development costs such as those of land levelling and shaping, field channels, field drains, improvement in facilities for storage, marketing, transport and communication. These costs have been estimated to be Rs 136 per acre and are relevant for the culturable command area at different sites (Sinha \& Bhatia 1976).

The social cost of investment for the dams and canals has been calculated by giving due consideration to the foreign exchange component, wage component due to unskilled labour and the construction period of the project. The social investment cost per unit has been calculated by applying the following formula.

$$
I=\sum_{t=1}^{\theta} \sum_{i} P_{i} I_{i}(t)(1+r)^{\theta-i}
$$




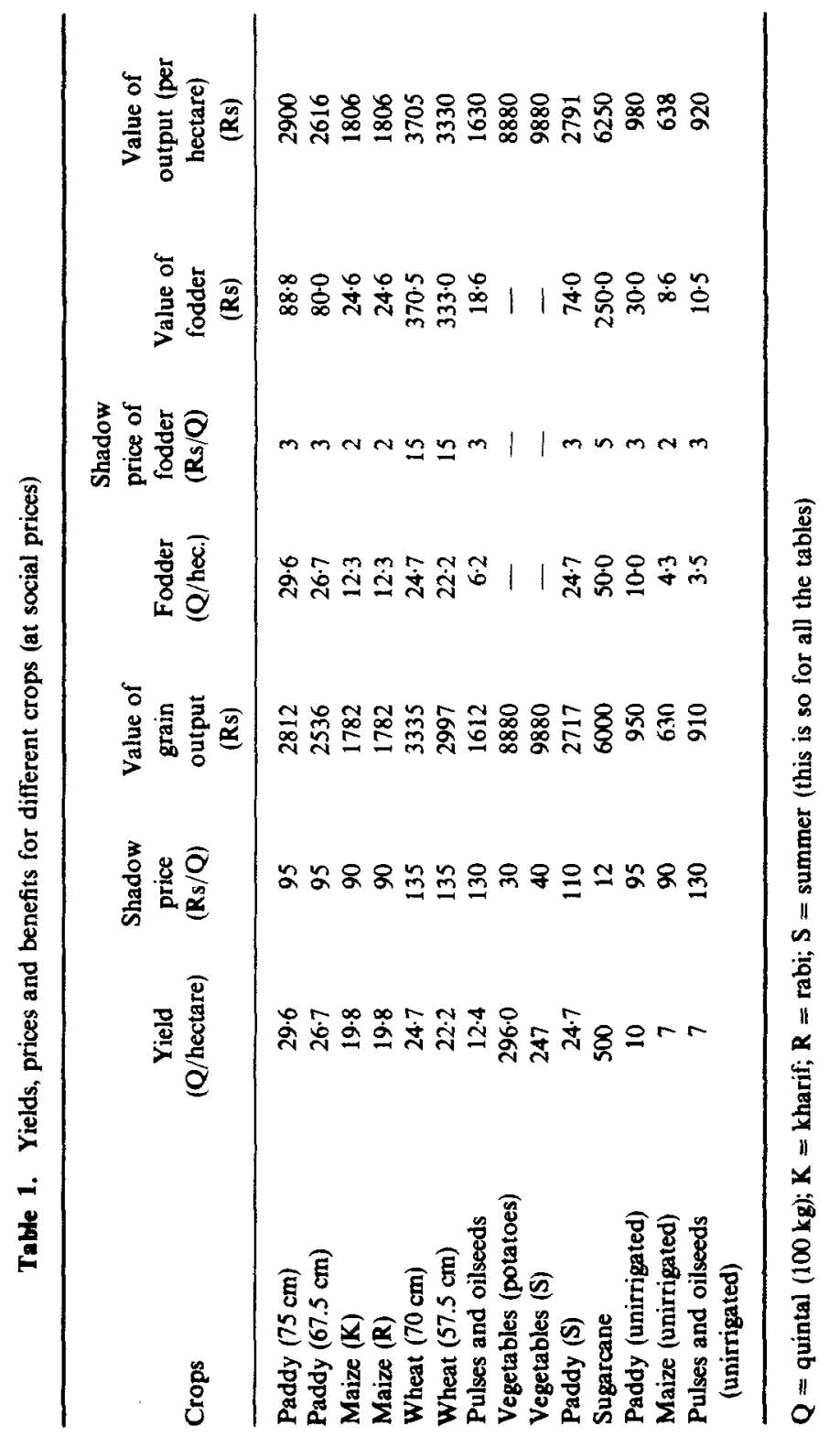


Table 2. Input costs of different crops (variable farm costs) (Rs/hectare) (at social prices)

\begin{tabular}{lrrrr}
\hline Crops & Seeds & $\begin{array}{c}\text { Human } \\
\text { labour }\end{array}$ & $\begin{array}{c}\text { Fertilizers } \\
\text { and pesticides }\end{array}$ & Total \\
\hline Paddy $(75 \mathrm{~cm})$ & 74 & 149 & 1093 & 1316 \\
Paddy (67.5 cm) & 74 & 149 & 1093 & 1316 \\
Maize (K) & 52 & 104 & 765 & 921 \\
Maize (R) & 52 & 104 & 765 & 921 \\
Wheat (70 cm) & 346 & 119 & 1201 & 1666 \\
Wheat (57.5 cm) & 346 & 119 & 1201 & 1666 \\
Pulses \& oilseeds & 242 & 83 & 841 & 1166 \\
Vegetables (R) & 1853 & 141 & 2298 & 4292 \\
Vegetables (S) & 1853 & 141 & 2298 & 4292 \\
Paddy (S) & 74 & 149 & 1093 & 1316 \\
Sugarcane & 642 & 206 & 3632 & 4480 \\
Paddy (unirrigated) & 45 & 129 & 62 & 236 \\
Maize (unirrigated) & 31 & 90 & 43 & 164 \\
Pulses and oilseeds & 111 & 60 & 86 & 257 \\
$\quad$ (unirrigated) & & & & \\
\hline
\end{tabular}

Table 3. Net benefits (at social prices) for different crops (Rs/hectare)

\begin{tabular}{|c|c|c|c|}
\hline Crops & Benefits & Cost & Net benefits \\
\hline Paddy & $2900 \cdot 8$ & $1316 \cdot 5$ & $1584 \cdot 3$ \\
\hline Paddy $(67.5 \mathrm{~cm})$ & $2616 \cdot 0$ & 1316.5 & $1299 \cdot 5$ \\
\hline Maize $(\mathbf{K})$ & $1806 \cdot 6$ & 921.9 & $884 \cdot 7$ \\
\hline Maize $(R)$ & $1806 \cdot 6$ & 921.9 & $884 \cdot 7$ \\
\hline Wheat $(70 \mathrm{~cm})$ & 3705.5 & $1666 \cdot 3$ & $2039 \cdot 2$ \\
\hline Wheat $(57.5 \mathrm{~cm})$ & $3330 \cdot 0$ & $1666 \cdot 3$ & $1663 \cdot 7$ \\
\hline Pulses \& oilseeds & $1630 \cdot 6$ & $1166 \cdot 2$ & $464 \cdot 4$ \\
\hline Vegetables (potatoes) & $8880 \cdot 0$ & 4292.0 & $4588 \cdot 0$ \\
\hline Vegetables $(\mathrm{S})$ & $9880-0$ & $4292 \cdot 0$ & $5588 \cdot 0$ \\
\hline Paddy (S) & $2791 \cdot 0$ & $1316 \cdot 5$ & 1474.5 \\
\hline Sugarcane & $6250 \cdot 0$ & $4480 \cdot 0$ & 17700 \\
\hline Paddy (unirrigated) & $980 \cdot 0$ & 2368 & 744.2 \\
\hline Maize (unirrigated) & $638 \cdot 6$ & $164 \cdot 3$ & $474 \cdot 3$ \\
\hline $\begin{array}{l}\text { Puises \& oilseeds } \\
\quad \text { (unirrigated) }\end{array}$ & $920-5$ & $258 \cdot 0$ & $662 \cdot 5$ \\
\hline
\end{tabular}

A construction period of 7 years has been assumed for the Kharkai and the Subernarekha dams. The investment cost has been annualised by assuming a capital recovery factor of $10.01 \%$ i.e. $10 \%$ social rate of discount and a 50-year life for the dams. We have also added the annualised maintenance and operating cost with the annualised investment cost of dams. The annualised maintenance and operating cost has been taken to be $2 \%$ of the investment cost. This includes labour, maintenance and overhead costs. The resulting estimates for annual costs are Rs 32.05 and Rs. 22.52 per thousand cu $\mathrm{m}$ for the Kharkai and the Subernarekha dams respectively. The capital costs of canals have also been annualized using the capital recovery factor mentioned above. These costs also include the cost of the Subernarekha and Kharkai barrages. 
The revenue from the sale of industrial water has been taken to be Rs. 61.32 per thousand cu $\mathrm{m}$.

The yield series for water for the two dams and the two barrages have been developed on the basis of rainfall series computed at each site separately. The rainfall runoff correlations which have been used for computing the yield series have been developed for Mango Weir (Jamshedpur site) at which runoff data were available for the period June 1961 to October 1973, assuming that the same will hold good at these dam and barrage sites. Since the Subernarekha waters have been allocated to the three cobasin states on the basis of an estimated $75 \%$ dependable annual water yield, the hydrological input in this model for the year in which the annual yield corresponded to $75 \%$ dependability is different for different control points. Therefore the adoption of different years for different sites in a static linear programming model could neither be considered appropriate nor consistent with the principle underlying the sharing of waters among the States on the basis of water yield as estimated at Kokpara at $75 \%$ dependability. Accordingly, the year corresponding to $75 \%$ dependability at the terminal structure, that is, the Subernarekha barrage site, was first found out in the 32 year series and the computed month wise yield in this year separately at each site has been utilized for this study. This procedure has also facilitated earmarking or reserving water for utilization from above the control points by excluding catchment areas in proportion to the $75 \%$ dependable water yield.

In this study for $75 \%$ dependability, the monthly runoffs net of project/protected utilization on the upstream of each site, corresponding to the year 1957-58 have been considered. An alternative solution considers the yield series for $1946-47$ which corresponds to $50 \%$ dependability at the terminal structure i.e. at Subernarekha barrage.

The economic and hydrologic data are given in tables 1 to 9.

\section{Results}

The results obtained from the model have been presented in the form of a Reference Solution (RS) as well as in terms of sensitizity analysis. The RS is based on the following assumptions: (i) $75 \%$ dependability factor for water availability (ii) no bounds on area under major irrigated crops such as paddy, wheat and maize, except for vegetables in rabi and summer (5\% of culturable command area (CCA) in each case); (iii) no upper bounds on capacities of dams and canals; (iv) minimum flow required at Subernarek ha barrage for downstream use; (v) bounds have been imposed on industrial water supply using exogeneously given estimates; (vi) upper bounds have been imposed on the following unirrigated crops: paddy (25\% of CCA), maize (15\% of CCA) and pulses and oilseeds ( $5 \%$ of CCA). The sensitivity analysis is presented mainly in terms of changes in relative prices of crops and area under different crops.

The results of the RS have been analyzed with respect to the following: (i) optimum cropping pattern suggesting area allocated to different crops in various seasons (i.e. in kharif, rabi and summer): (ii) the optimum capacities of the two reservoirs and the associated releases for irrigation, industrial water supply and downstream uses; and (iii) the associated diversions from the two barrages for the above-mentioned uses.

Table 5 presents the optimum cropping pattern in the RS and tables 6-9 give the corresponding water balances at each of the 4 sites. It may be seen that irrigation intensity (gross area irrigated as a ratio of culturable command area) for the two dams 


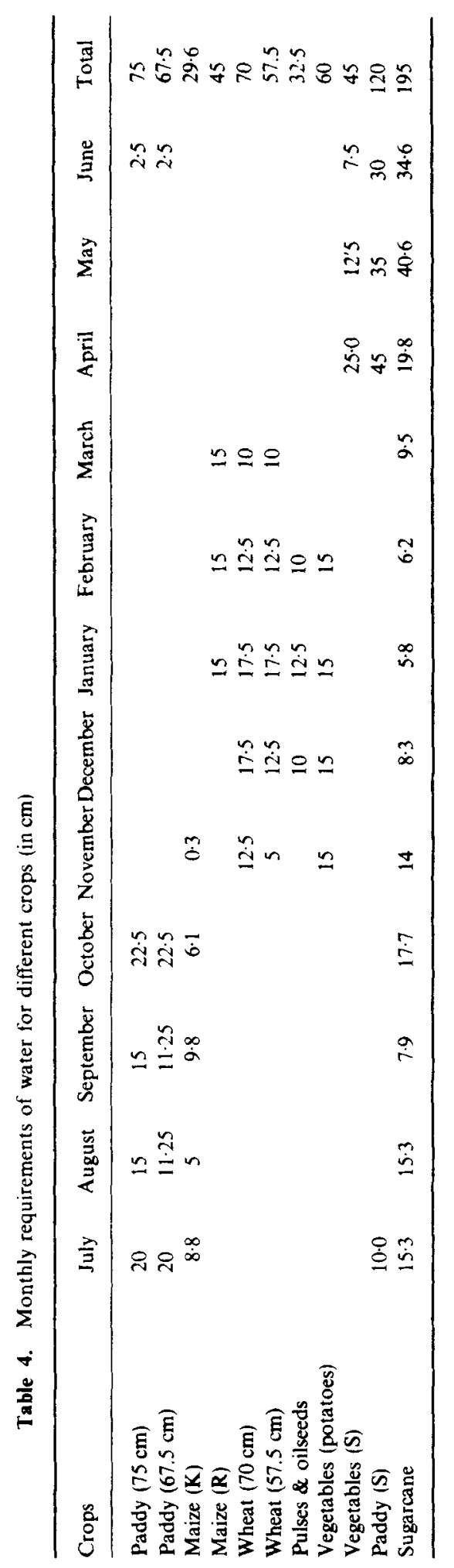


varies from $108 \%$ for the Kharkai dam and $129 \%$ for the Subernarekha dam. The irrigation intensity for the Kharkai barrage is $136 \%$ while it is $179 \%$ for the Subernarekha barrage. The crops in the kharif (monsoon) season are irrigated maize, unirrigated maize and unirrigated paddy for the Kharkai and Subernarekha dams.

Table 5. Optimum cropping pattern in the reference solution $(75 \%$ dependability factor) (in thousand hectares)

\begin{tabular}{|c|c|c|c|c|}
\hline & $\begin{array}{c}\text { Kharkai } \\
\text { dam }\end{array}$ & $\begin{array}{l}\text { Kharkai } \\
\text { barrage }\end{array}$ & $\begin{array}{c}\text { Subernarekha } \\
\text { dam }\end{array}$ & $\begin{array}{c}\text { Subernarekha } \\
\text { barrage }\end{array}$ \\
\hline \multicolumn{5}{|l|}{ Kharif } \\
\hline Unirrigated paddy & $16 \cdot 2$ & 0 & $19 \cdot 5$ & $2 \cdot 4$ \\
\hline Irrigated paddy $(75 \mathrm{~cm})$ & 0 & $8 \cdot 5$ & 0 & $7 \cdot 3$ \\
\hline Irrigated paddy $(67.5 \mathrm{~cm})$ & 0 & 0 & 0 & 0 \\
\hline Unirrigated maize & $9 \cdot 7$ & 0 & $11 \cdot 3$ & 0 \\
\hline Irrigated maize & $28 \cdot 3$ & 0 & $34 \cdot 8$ & 0 \\
\hline \multicolumn{5}{|l|}{ Rabi } \\
\hline Irrigated wheat $(70 \mathrm{~cm})$ & $35 \cdot 2$ & 0 & $58 \cdot 3$ & 0 \\
\hline Irrigated vegetables & $2 \cdot 8$ & 0.4 & $3 \cdot 3$ & 0.4 \\
\hline Unirrigated pulses \& oil seeds & $3 \cdot 3$ & 0.4 & 4 & 0.4 \\
\hline Wheat $(57.5 \mathrm{~cm})$ & 0 & $3 \cdot 6$ & 0 & 9 \\
\hline \multicolumn{5}{|l|}{ Summer } \\
\hline Irrigated vegetables & $2 \cdot 8$ & 0.4 & $3 \cdot 3$ & 0.4 \\
\hline Irrigated paddy & 0 & 0.4 & 0 & $3 \cdot 3$ \\
\hline Gross cropped area (A) & $98 \cdot 4$ & $13 \cdot 8$ & $134 \cdot 4$ & 23 \\
\hline Gross irrigated area (B) & $69 \cdot 2$ & $13 \cdot 4$ & 100 & 202 \\
\hline Culturable command area (C) & 64 & 10 & 77 & $11 \cdot 3$ \\
\hline Intensity of cropping $(\mathrm{A} / \mathrm{C})(\%)$ & 154 & 136 & 175 & 204 \\
\hline Intensity of irrigation $(\mathrm{B} / \mathrm{C})(\%)$ & 108 & 132 & 129 & 179 \\
\hline
\end{tabular}

Table 6. Inflow and outflow balances for the Kharkai dam in the reference solution (m cu m)

\begin{tabular}{|c|c|c|c|c|c|}
\hline \multirow[b]{2}{*}{ Month } & \multirow[b]{2}{*}{ Inflow } & \multicolumn{2}{|c|}{ Diversion to } & \multirow[b]{2}{*}{$\begin{array}{c}\text { Reservoir } \\
\text { losses }\end{array}$} & \multirow[b]{2}{*}{$\begin{array}{l}\text { Storage at } \\
\text { the end of } \\
\text { the month }\end{array}$} \\
\hline & & Irrigation & $\begin{array}{l}\text { Kharkai } \\
\text { barrage }\end{array}$ & & \\
\hline July & 393.5 & 26 & 0 & - & $361 \cdot 4$ \\
\hline August & 130.0 & 14.8 & 0 & 2.5 & $467 \cdot 5$ \\
\hline September & $278 \cdot 8$ & $28 \cdot 4$ & 0 & 3.7 & $708 \cdot 0$ \\
\hline October & 5.0 & $17 \cdot 3$ & 140 & $3 \cdot 7$ & $546 \cdot 5$ \\
\hline November & $3 \cdot 7$ & $49 \cdot 3$ & 0 & $6 \cdot 15$ & 488.5 \\
\hline December & $1 \cdot 23$ & $66 \cdot 6$ & $2 \cdot 5$ & $6 \cdot 15$ & $408 \cdot 3$ \\
\hline January & $2 \cdot 5$ & 66.6 & $2 \cdot 5$ & 3.7 & 331.8 \\
\hline February & 18.5 & $48 \cdot 0$ & 0 & 5 & $291 \cdot 0$ \\
\hline March & $3 \cdot 7$ & $48 \cdot 0$ & $1 \cdot 23$ & 3.7 & $248 \cdot 0$ \\
\hline April & $2 \cdot 5$ & $7 \cdot 4$ & 0 & $3 \cdot 7$ & 233.0 \\
\hline May & 0 & 3.7 & 0 & $6 \cdot 15$ & $217 \cdot 0$ \\
\hline June & 0 & $2 \cdot 5$ & 0 & 5 & $203 \cdot 5$ \\
\hline
\end{tabular}

Diversion to industrial water supply during all the months has been taken as $6 \cdot 15 \mathrm{mcu}$ m. 
Table 7. Inflow and outflow balances for the Kharkai barrage in the reference solution ( $\mathrm{m}$ cu $\mathrm{m}$ )

\begin{tabular}{|c|c|c|c|c|c|c|c|}
\hline \multirow{2}{*}{ Month } & \multirow{2}{*}{$\begin{array}{c}\text { Hydrolo } \\
\text { gical } \\
\text { input }\end{array}$} & \multirow[b]{2}{*}{$\begin{array}{l}\text { Inflow } \\
\text { from } \\
\text { Kharkai } \\
\text { dam }\end{array}$} & \multirow[b]{2}{*}{$\begin{array}{c}\text { Return } \\
\text { flow } \\
\text { from } \\
\text { irriga- } \\
\text { tion by } \\
\text { Kharkai } \\
\text { dam }\end{array}$} & \multirow{2}{*}{$\begin{array}{l}\text { Total } \\
\text { Inflow }\end{array}$} & \multicolumn{2}{|c|}{ Diversions to } & \multirow{2}{*}{$\begin{array}{c}\text { Total } \\
\text { diversion }\end{array}$} \\
\hline & & & & & $\begin{array}{l}\text { Irri- } \\
\text { gation }\end{array}$ & $\begin{array}{l}\text { Flow for } \\
\text { down- } \\
\text { stream use } \\
\text { at Suberna- } \\
\text { rekha barrage }\end{array}$ & \\
\hline July & $50 \cdot 6$ & 0 & 1.23 & $56 \cdot 8$ & $19 \cdot 7$ & $33 \cdot 4$ & 56.8 \\
\hline August & 146.8 & 0 & 0 & 151.8 & 19.7 & 128.4 & 151.8 \\
\hline September & $251 \cdot 6$ & 0 & $1 \cdot 23$ & 257.8 & 19.7 & $234 \cdot 4$ & 2578 \\
\hline October & 5 & $125 \cdot 8$ & 0 & 135.8 & $19 \cdot 7$ & $122 \cdot 1$ & 145.5 \\
\hline November & 0 & 0 & $1 \cdot 23$ & 6.23 & $2 \cdot 5$ & 0 & 6.2 \\
\hline December & 0 & $2 \cdot 5$ & $2 \cdot 5$ & 10 & 5 & 0 & 8.7 \\
\hline January & $2 \cdot 5$ & $2 \cdot 5$ & $2 \cdot 5$ & $12 \cdot 5$ & $7 \cdot 5$ & 1.23 & 12.5 \\
\hline February & $2 \cdot 5$ & 0 & $1 \cdot 23$ & $8 \cdot 7$ & 5 & 0 & 8.7 \\
\hline March & 1.23 & 1.23 & 1.23 & 8.7 & $3 \cdot 7$ & 0 & $7 \cdot 4$ \\
\hline April & 1.23 & 0 & 0 & 6.23 & $2 \cdot 5$ & 0 & 6.2 \\
\hline May & 1.23 & 0 & 0 & 6.23 & $2 \cdot 5$ & 0 & $6 \cdot 2$ \\
\hline June & $2 \cdot 5$ & 0 & 0 & $7 \cdot 5$ & $3 \cdot 7$ & 0 & $7 \cdot 4$ \\
\hline
\end{tabular}

Return flow from industrial water supply by Kharkai dam during all the months is $5 \mathrm{~m} \mathrm{cu} \mathrm{m}$. The diversion to industrial water supply is $3.7 \mathrm{~m} \mathrm{cu} \mathrm{m}$ in all cases.

Table 8. Inflow and outflow balances for Subernarekha dam in the reference solution ( $\mathrm{m}$ cu $\mathrm{m}$ )

\begin{tabular}{|c|c|c|c|c|c|}
\hline \multirow[b]{2}{*}{ Month } & \multirow[b]{2}{*}{ Inflow } & \multicolumn{2}{|c|}{ Diversions to } & \multirow[b]{2}{*}{$\begin{array}{c}\text { Reservoir } \\
\text { losses }\end{array}$} & \multirow[b]{2}{*}{$\begin{array}{l}\text { Storage at } \\
\text { the end of } \\
\text { the month }\end{array}$} \\
\hline & & Irrigation & $\begin{array}{c}\text { Subernarekha } \\
\text { barrage }\end{array}$ & & \\
\hline July & 680.6 & $30 \cdot 8$ & 0 & 1.23 & $606 \cdot 6$ \\
\hline August & 177.6 & $17 \cdot 3$ & 0 & $6 \cdot 2$ & 718.8 \\
\hline September & $617 \cdot 7$ & $34 \cdot 5$ & 0 & 6.2 & 1254 \\
\hline October & $50 \cdot 6$ & 21 & 21 & 10 & 1211 \\
\hline November & $12 \cdot 33$ & 80 & 16 & 13.6 & $1071 \cdot 5$ \\
\hline December & $3 \cdot 7$ & $108 \cdot 5$ & 25 & 15 & $885 \cdot 3$ \\
\hline January & $5 \cdot 0$ & $108 \cdot 5$ & $28 \cdot 4$ & 13.6 & 698 \\
\hline February & $34 \cdot 5$ & $39 \cdot 5$ & 0 & $11 \cdot 1$ & 640 \\
\hline March & $2 \cdot 5$ & $59 \cdot 2$ & 0 & 10 & 531.4 \\
\hline April & 0 & $8 \cdot 6$ & 0 & $11 \cdot 1$ & 470 \\
\hline May & 0 & 3.7 & 0 & 15 & $409 \cdot 4$ \\
\hline June & 0 & $2 \cdot 5$ & 0 & 136 & $351 \cdot 4$ \\
\hline
\end{tabular}

Diversion to industrial water supply is $42 \mathrm{~m}$ cu $\mathrm{m}$ in all cases.

Irrigated paddy is the main crop for the two barrages. For rabi (winter) season, the major crop is irrigated wheat (around $60-70 \%$ of CCA) along with some area under pulses and oil seeds and vegetables. The crops for the summer are irrigated paddy at the Subernarekha barrage and vegetables at the other sites. Crops with higher water 


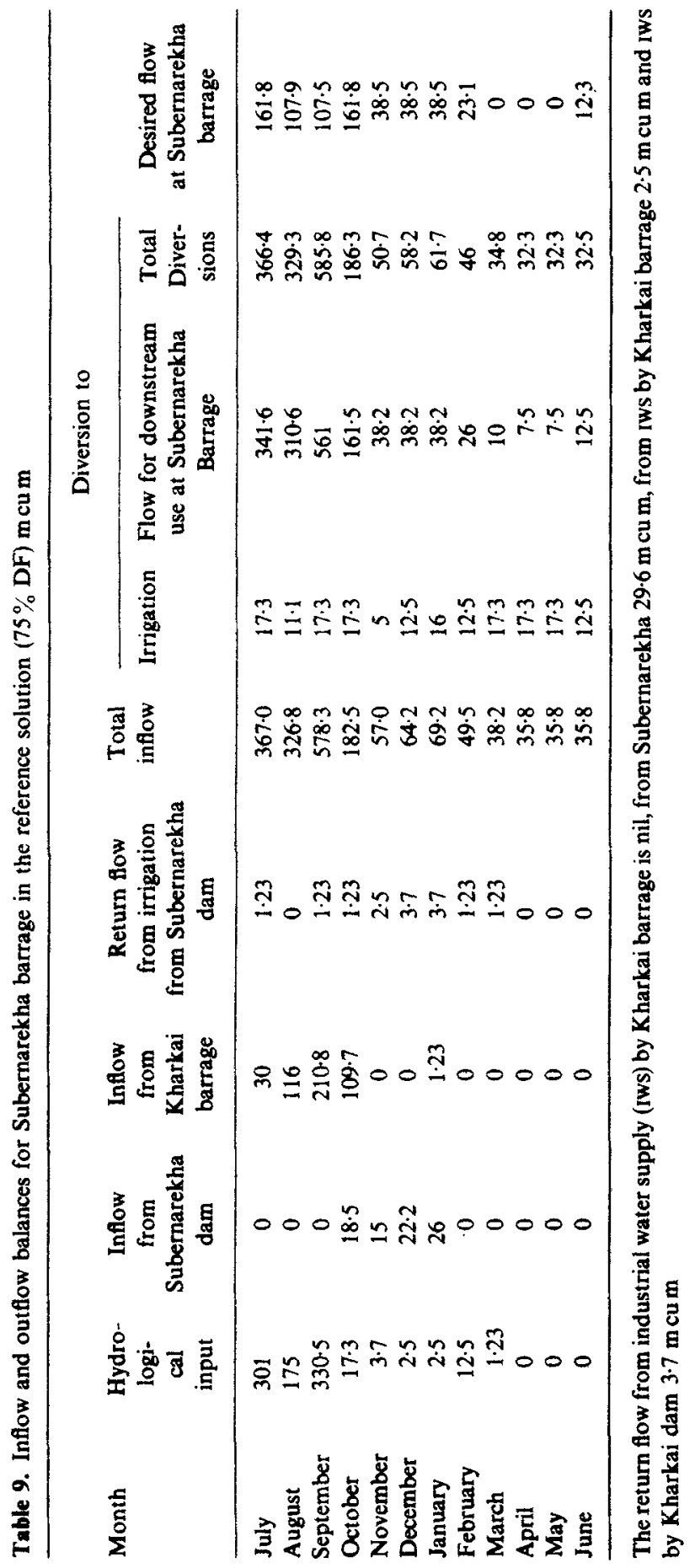


requirements had a substantially greater yield than crops with lower water requirement although the fixed costs were the same. For this reason the former crops have been preferred to the latter.

The solution suggests that the optimum economic use of water would be to use it mainly on maize in the kharif season (around $45 \%$ of CCA) and wheat in the rabi season. It is economic to add adequate storage capacities in the two reservoirs such that available water yield in the monsoon period is carried over to the next season for use in the rabi crops. This is because the net social value of wheat per hectare is Rs $\mathbf{2 0 4 0}$ compared with Rs 1584.30 per hectare of paddy, although the total water requirement for wheat $(70 \mathrm{~cm})$ is less than that for paddy $(75 \mathrm{~cm})$. Even within kharif crops, irrigated maize is preferred over irrigated paddy on account of lower water requirements although the yield (and the benefit) for maize is lower than that for paddy.

These results have to be analyzed further by changing the assumptions regarding (i) net benefit from wheat to net benefit from other crops (ii) preference of consumers for rice vis-a-vis wheat or maize. In table 10 we have presented the results of changes in optimum cropping pattern when the net benefit from wheat is parametrically decreased up to $40 \%$ of the estimated value in the RS. There is no significant change in the cropping pattern until the net benefit from wheat is decreased to $60 \%$ of its level in the RS. When the wheat benefit is reduced by $40 \%$, substantial area is allocated to irrigated paddy in the kharif and irrigated maize in the rabi seasons. In the rabi season, the entire area under wheat gets shifted to irrigated maize and in the kharif, area under maize gets reallocated to paddy. The area under irrigated paddy during the kharif also increases mainly on account of the total available area in the rabi season going to irrigated maize. If additional crop area was available, the model may have preferred to store more water in the kharif to be used later in the rabi season.

Table 11 shows the optimal cropping pattern when at least $65 \%$ of the land is assumed to be under paddy cultivation to reflect the consumer preference for rice. When comparing this table with table 5 we see that: (i) the irrigated maize has been almost totally replaced by irrigated paddy in both dams and (ii) the irrigated wheat $(70 \mathrm{~cm})$ cultivated has been decreased by half in the Kharkai Dam and by about a third in the Subernarekha dam, while the unirrigated crops have not been affected.

Although the benefit from irrigated maize is about two times that from unirrigated maize, it is substantially lower than that of irrigated wheat. So the cropping pattern is in favour of using the kharif land for unirrigated maize and saving the water for wheat in the rabi season. Since the requirement of water for paddy is about twice that for irrigated maize, the increase in paddy cultivation increased the diversion of water from the dams for irrigation. Thus the water yield in the kharif season carried over to the rabi season is less than before. This in turn reduces the irrigated area under wheat as reflected in the results.

The capacities of the two reservoirs do not change significantly until the net benefit from wheat decreases by 35 to $40 \%$. In the RS the optimum storage capacity of the Kharkai dam is $707.8 \mathrm{mcum}$ (table 6). This is lower than the capacity planned at present, which also takes into account the carryover storage from year to year besides carryover from season to season. The optimum storage capacity for the Subernarekha dam is $1254 \mathrm{~m}$ cu $\mathrm{m}$ (table 8 ). This is only marginally less than the $1470 \mathrm{~m}$ cu m planned. The optimum capacities in the solution with lower net benefit $(60 \%$ of that in the rs) are $616.5 \mathrm{~m} \mathrm{cum}$ and $1233 \mathrm{mcu} \mathrm{m}$ (table 10 ). 


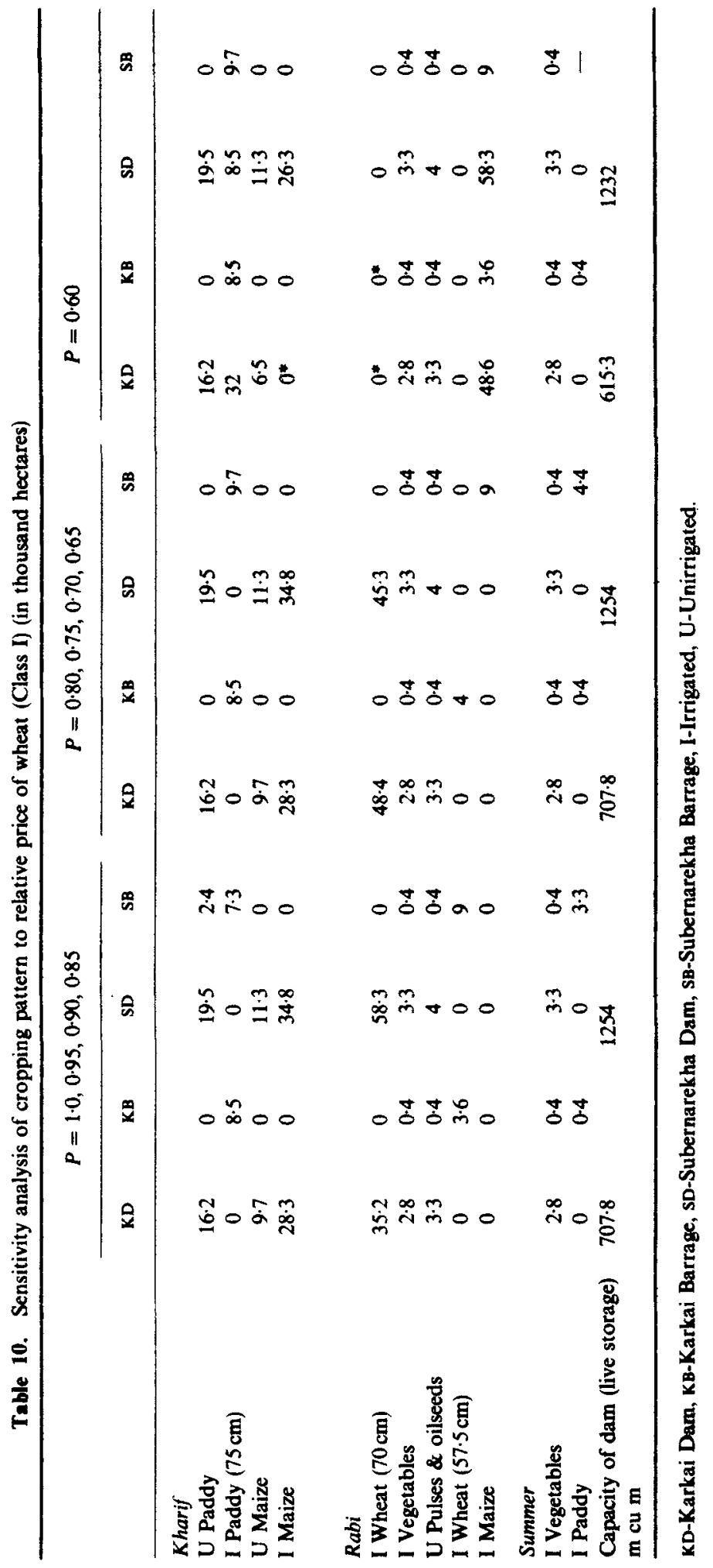


Table 11. Optimum cropping pattern in Reference Solution with lower bounds on paddy (in thousand hectares)

\begin{tabular}{|c|c|c|c|c|}
\hline & $\begin{array}{c}\text { Kharkai } \\
\text { dam }\end{array}$ & $\begin{array}{l}\text { Kharkai } \\
\text { barrage }\end{array}$ & $\begin{array}{c}\text { Suberna } \\
\text { rekha } \\
\text { dam }\end{array}$ & $\begin{array}{c}\text { Suberna } \\
\text { rekha } \\
\text { barrage }\end{array}$ \\
\hline \multicolumn{5}{|l|}{ Kharif } \\
\hline Unirrigated paddy & $16 \cdot 2$ & 0 & $19 \cdot 5$ & 2 \\
\hline Irrigated paddy $(75 \mathrm{~cm})$ & $25 \cdot 5$ & $8 \cdot 5$ & 30.8 & 7.7 \\
\hline Irrigated paddy $(67.5 \mathrm{~cm})$ & 0 & 0 & 0 & 0 \\
\hline Unirrigated maize & $9 \cdot 7$ & 0 & $11 \cdot 3$ & 0 \\
\hline Irrigated maize & $2 \cdot 8$ & 0 & 4 & 0 \\
\hline \multicolumn{5}{|l|}{ Rabi } \\
\hline Irrigated wheat $(70 \mathrm{~cm})$ & 18 & 0 & 38 & 0 \\
\hline Irrigated wheat $(57.5 \mathrm{~cm})$ & 0 & $3 \cdot 3$ & 0 & $8 \cdot 9$ \\
\hline Unirrigated pulses and oil seeds & $3 \cdot 3$ & 0.4 & 4 & 0.4 \\
\hline Irrigated Vegetables & $2 \cdot 8$ & 0.4 & $3 \cdot 3$ & $0-4$ \\
\hline \multicolumn{5}{|l|}{ Summer } \\
\hline Irrigated vegetables & $2 \cdot 8$ & 0.4 & $3 \cdot 3$ & 0.4 \\
\hline Irrigated paddy $(75 \mathrm{~cm})$ & 0 & 0.4 & 0 & 3.7 \\
\hline Gross cropped area $(A)$ & $80 \cdot 3$ & $13 \cdot 4$ & $114 \cdot 2$ & $23 \cdot 5$ \\
\hline Gross irrigated area $(B)$ & $52 \cdot 2$ & 13 & $79 \cdot 3$ & 21 \\
\hline Culturable command area $(C)$ & 64 & 10 & 77 & $11 \cdot 3$ \\
\hline Intensity of cropping $(A / C)(\%)$ & 127 & 132 & 148 & 207 \\
\hline Intensity of irrigation $\left(B / C,\left(\begin{array}{l}0 \\
0\end{array}\right)\right.$ & 82 & 128 & 103 & 186 \\
\hline
\end{tabular}

To summarize, the tentative results do indicate the importance of analyzing the possible choices available in utilization of water for different crops. It seems more economical to increase the storage capacities mainly for use in the rabi season when rainfall is relatively lower than in the kharif season. Since optimum cropping pattern depends on many other agro-economic variables besides water supply, such as size and ownership of land, availability of inputs, farmer's attitude to risk, home-consumption requirements and consumer's preferences, there is need for more disaggregated analysis of interaction between irrigation planning and related agroeconomic variables. 
Planning for the Subernarekha river system

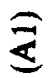

氕要

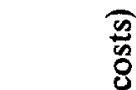

总

ह

솔

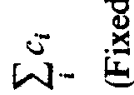

$\rightarrow$ 동

$=11 \%$

站暠

बิ

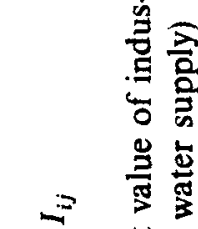

11

$\bar{W}=\ddot{Z}$

$+$

5

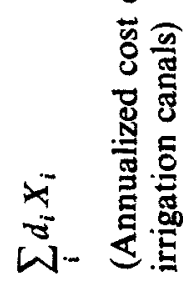

궁

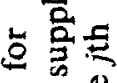

몽. 폴

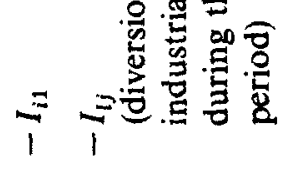

$\pm$

훙홀

폴

次

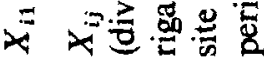

1

4

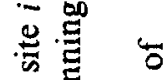

W.

क

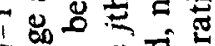

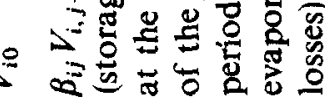

$\stackrel{\frac{\pi}{2}}{5}$

$++$

氙:

㔛

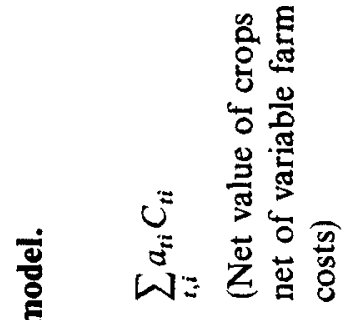
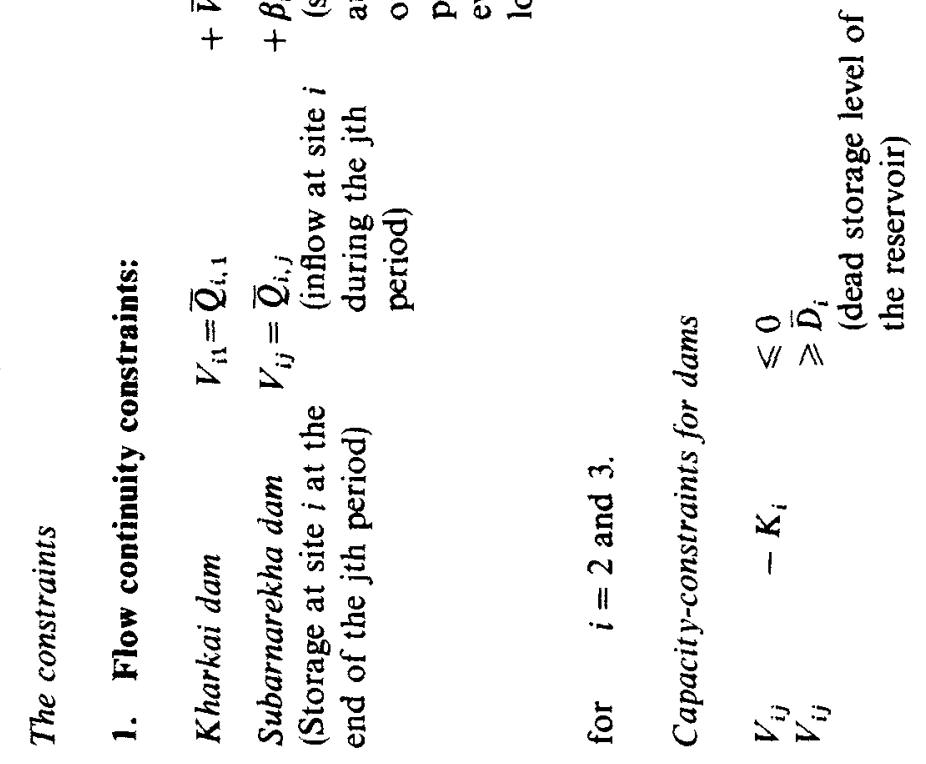


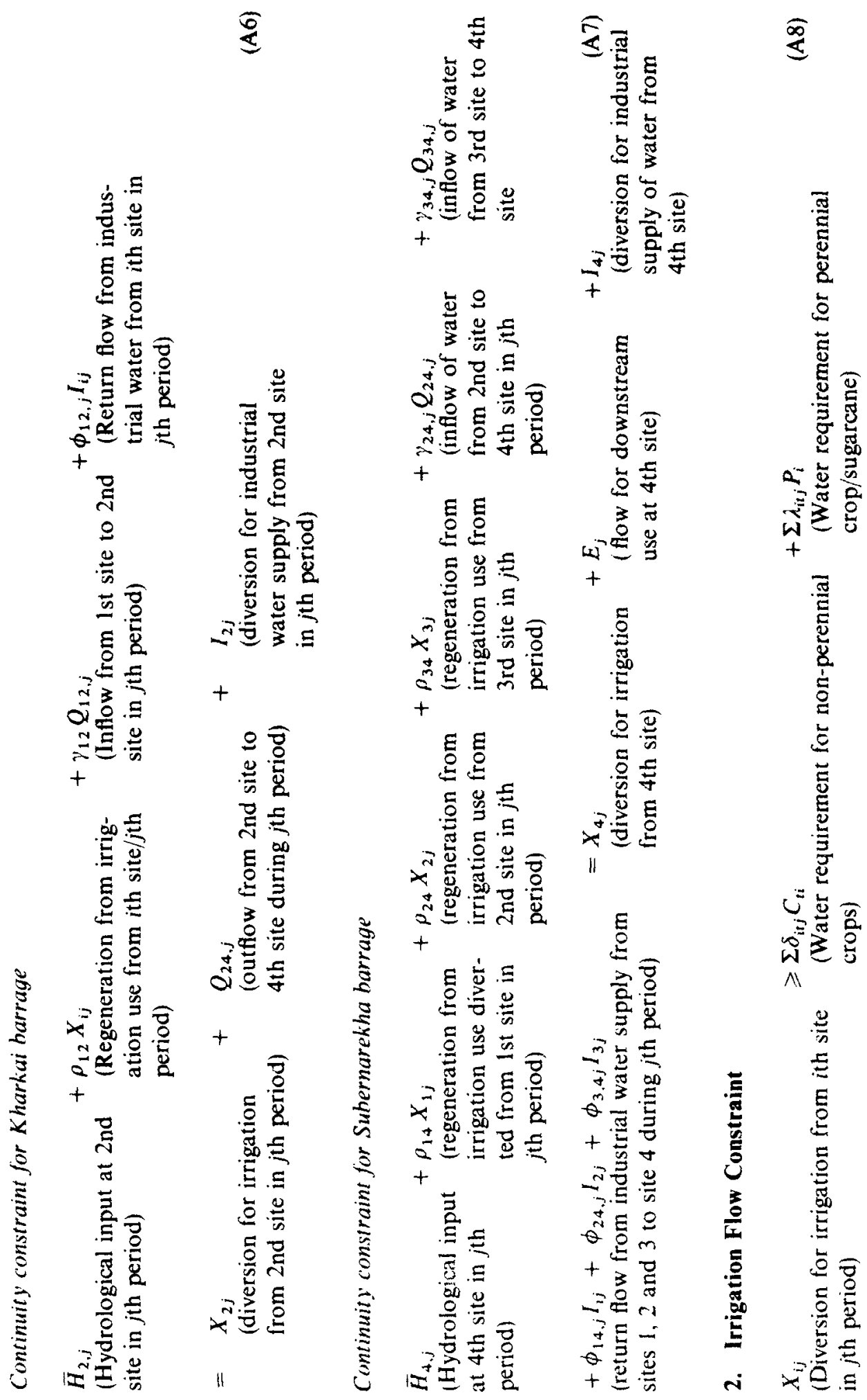



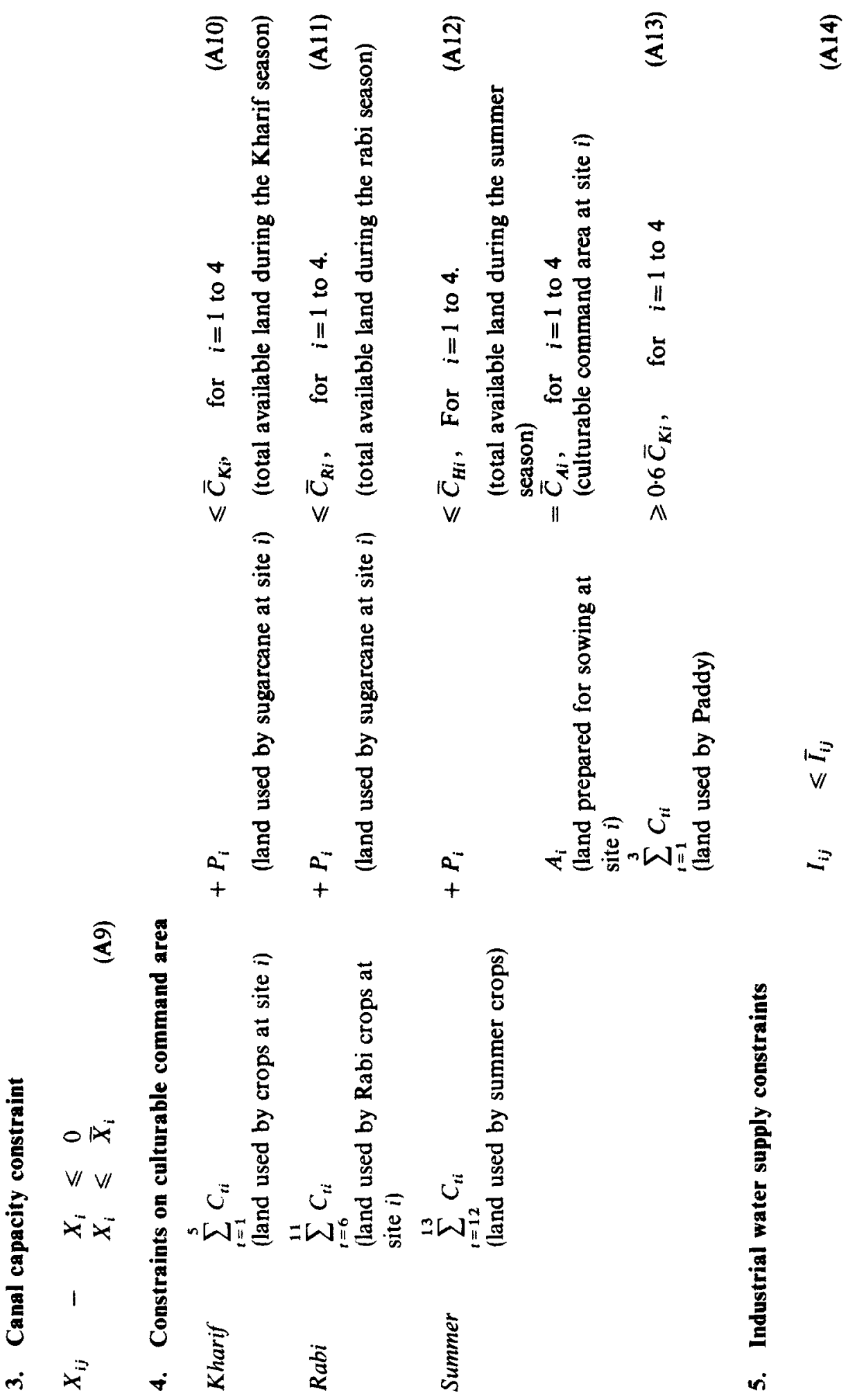


\section{List of indices and symbols}

Indices

$i=1 \quad$ Kharkai reservoir at Icha

2 Kharkai barrage at Bhua

3 Subernarekha reservoir at Chandil

4 Subernarekha barrage at Galudih

$t=1 \quad$ kharif unirrigated paddy.

2 kharif irrigated paddy $(75 \mathrm{~cm})$.

3 kharif irrigated paddy $(67.5 \mathrm{~cm})$.

4 kharif unirrigated maize.

5 kharif irrigated maize.

6 rabi irrigated wheat $(70 \mathrm{~cm})$

7 rabi irrigated wheat $(57.5 \mathrm{~cm})$

8 rabi irrigated pulses and oilseeds,

9 rabi unirrigated pulses and oilseeds,

10 rabi irrigated maize

11 rabi irrigated vegetables,

12 summer irrigated vegetables

13 summer irrigated paddy

14 perennial sugarcane

(The figures in brac'? yields are adopted)

Symbols

$a_{i i} \quad$-net value of crop $t$ at site $i$ (Rs million per thousand hectares)

$b_{i} \quad$-annualised cost of reservoir $i$ (Rs million per $\mathrm{m}$ cu $\mathrm{m}$ ) for $i=1,3$ )

$C_{t i} \quad-$ land used by crop $t(t=1$ to 10$)$ at site $i(i=1$ to 4$)$

$c_{i} \quad-$ coefficient of fixed cost at site $i$

$d_{i} \quad$-annualised cost of canals, including cost of barrage at sites 2 and 4 , at site $i$ (Rs million per $\mathrm{m} \mathrm{cu} \mathrm{m}$ )

$E_{j} \quad-$ flow for downstream use at Subernarekha Barrage during the $j$ th period

$f_{i j} \quad-$ unit value of industrial water supply at site $i$ during the $j$ th period (Rs million per $\mathrm{m} \mathrm{cu} \mathrm{m}$ )

$I_{i} \quad$-investment per thousand cu $\mathrm{m}$

$I_{i j} \quad-$ Industrial water supply from site $i$ during period $j(j=1$ to 12$)$

$I_{i}(t) \quad$-investment cost due to the $i$ th element in the $t$ th period

$K_{i} \quad$-capacity of the $i$ th reservoir

$P_{i} \quad-$ land used by the perennial crop (sugarcane) at site $i$ (in (A1)-(A14); the appropriate shadow price-of the $i$ th element in investment cost (in (1)).

$Q_{i k, j} \quad$ - - flow of water from site $i$ to site $k$ during the $j$ th period 


\begin{tabular}{|c|c|}
\hline$r$ & - the rate of interest \\
\hline$t$ & -the running time variable \\
\hline$V_{i j}$ & -storage of water at site $i$ at the end of the $j$ th period \\
\hline$X_{i}$ & - capacity of irrigation canal at site $i$ \\
\hline$X_{i j}$ & -flow of irrigation water from site $i$ during period $j$ \\
\hline$\beta_{i j}$ & -reservoir losses at the ith site during the $j$ th period \\
\hline$\gamma_{i k, j}$ & efficiency coefficient for flow from site $i$ to site $k$ during the $j$ th period \\
\hline$\delta_{i t, j}$ & 一water required by crop $t$ at site $i$ during the $j$ th period $(\mathrm{cm})$ \\
\hline$\phi_{i k, j}$ & $\begin{array}{l}\text { coefficient of return flow from industrial water supply from the } i \text { th site } \\
\text { to the } k \text { th site } / j \text { th period }\end{array}$ \\
\hline$\lambda_{i t, j}$ & -water required by sugarcane during the $j$ th period $(\mathrm{cm})$ \\
\hline$\rho_{i k, j}$ & $\begin{array}{l}\text { coefficient of return flow from the } i \text { th site to the } k \text { th site during the } j \text { th } \\
\text { period }\end{array}$ \\
\hline$\theta$ & the total number of years for the construction of the project \\
\hline
\end{tabular}

\section{References}

Ministry of Agriculture 1971 A guide for estimating irrigation water requirements, Tech. Ser. No. 2, Water Management Division, New Delhi

Ministry of Irrigation and Power 1972 Report of the Irrigation Commission, Government of India, Delhi (3 volumes)

Sinha B, Bhatia R 1976 Economic appraisal of irrigation projects in India, Harvard University, Centre for Population Studies 